\title{
Athapahariyas: A Geographical Perspective
}

\author{
Shambhu Prasad Khatiwada, PhD \\ Reader, Central Department of Geography, Tribhuvan University \\ Email for correspondence: geography.dmc@gmail.com
}

\begin{abstract}
Cultural geography attempts to real-life situations of Athapahariyas in Dhankuta district. Their sense of place bring to where they live, how they shape their way of living to respond in this place. Their socio-economic and political changes are also reshaped by the place or surrounding habitat. In this context, this effort is made a valuable literature for detailed socio-economic and cultural studies as a lane of folklore geography with concerning theories of sense of place. The main objective of this paper is to analyse some aspects of the Athapahariyas and seeks to answer meaning of places as an aspect of environmental experiences.
\end{abstract}

Key words: Athapahariya, cultural geography, place, home, territory and locale.

\section{Introduction}

The progress in cultural geography attempts to understand the real life situations of a particular ethnic group in a particular area. Culture is a simple concept in geography, which seeks to the study of places and to analyse the complexity of habitual activities, which characterizes a human group and provides the foundation for its existence (Sorre, 1962). It reflects some fundamental aspects of community that relates to the cultural environments. It is clear that culture in geography is associated in place which has come increasingly to be understood as experiential and social phenomena consisting of territories of meanings and subject to all the inconsistencies of everyday life (Relph, 1996). Relph points out such things as familiarity, detachment, social status, gender and self-consciousness to determine type and intensity of place. The character of a place has interconnected in a particular environment and cultural group. Place is a simple concept because it began to think about how places are experienced by collectively or individually. Most of the cultures develop in places and are passed on in places. Cultures are continually changing and have no existence independent of the people who use them (Johnston, 1999). We are socialized into places bound to home and work in a space-time prism and we are rooted as social beings in places. It has been considered that our material and spiritual value is evident upon the meaning of the place (Jensen, 2004, p.155).

It was straightforward to the Athapahariyas' culture, which is transmitted by tradition that enables them to live in the eastern hills of Nepal, especially in Dhankuta district (Khatiwada, 2006). The etymological meaning of the Athapahariya is not clear. It is derived from Nepali word 'aathapahar'.

NUTA JOURNAL, 6 (1\&2), 2075 : ISSN: 2616 - 017x 
The first half may be related to the number 'aatha' meaning eight and the second half of the term stems from 'pahar' meaning time of three hours. The word 'aathapahar' which denotes to a person who dedicated to work for the whole day at Nishan Bhagawati (Srijanga Paltan) during the Dashai festival and the Shah King had given them the tile of 'Athapahariya' (Dahal, 1985; Rai, 2007), but has over the years become the popular generic term of reference for an ethnic of Rai community. Out of total population $26,494,504$ there are $2.3 \%$ or 620,004 Rai people in Nepal (CBS, 2011). The name of the Athapahariya has pronounced variously by different scholars, namely, Atpahare by Northey and Morris (1974), Athapre by Bista (1960) and Attepre by Prapannacharya (1994). Rai tribe includes a number of Thar segments which in turn may be further subdivided. Each Thar is representative of a particular locale and a group of settlements of the Athapre close proximate to Dhankuta (Bista, 1960, p. 18).

The Athapahariya has a tradition that they, too, came from Banaras (India) and Lhasa (Tibet) as the same origin of the Rai ethinic groups. Originally, they have come from Lhasa, known as Lhasa 'Gotra' and known as Kashigotra, from Banaras (Khatiwada, 2006). The social structure of the Athapahariyas has divided into two major clan groups namely Khambongba (aboriginal) and Thangbongba (emigrants) although they are considered 'as the descendent of the Das Kirant' (Northey \& Morris, 1974, p. 38). They are called Jimdar indeed it was also used for entire ethnic of Rai (Bista, 1960; Dahal, 1985) and mostly speak Tibeto-Burman dialect which is known as Athapahare language. Their mongoloid appearance, yellowish pigmentation and flat face with almond shaped eyes make them distinguishable from other living near them in Dhankuta bazaar.

All these evidences show the Athapahariyas posses different attributes, namely it lives in an isolated area as a distinct group culturally and ethnically; it originates from one of the oldest ethnological sections of the Kiranti people; and it is usually backward economically, socially and educationally due to lack of government priority. On the other hand, they have attracted themselves of the attention of a large number of socio-economic and political changes in their surrounding habitat. Their effort made a valuable literature for detailed socio-economic and cultural studies as a lane of folklore geography. But, they have received little attention that charmed with their way of life concerning theories of sense of place, it depends very much on familiarity: there are noticeable differences between an insider's and insiders' experiences.

\section{Research Objectives}

- To explore social and cultural structures of the Athapahariya Rais.

- To understand relationships between Athapahariyas and different places.

\section{Research Design}

The main objective of this paper was to understand some aspects of the Athapahariyas and seeks to answer meaning of places as an aspect of environmental experience in the sense of the Athapahariyas in geography. Hence, under qualitative case study research design, I applied descriptive and analytical methods to understand researching issues (Yin, 2003). In doing so, I collected information by applying conversations and observation techniques. Prior to field, reconnaissance survey was conducted to establish the rapport with key persons' selected purposively from Chharagaun, Thoka, Santang and Yakte villages of Dhankuta Municipality or case of my study. And the unit of analysis is understanding 
and knowledge on folklore and geography of the key informants about Athapahariya community. More specifically unstructured interview guideline was used for in-depth interview and checklist was used for observing their social meanings and ordinary activities in their locality in 2013. The collected information was transcribed, cross checked and thematized for meaning making being imposed by the Athapahariyas.

\section{Social Structure: Clans and Sub-clans of Athapahariya Rais}

The Athapahariyas who claim that they belong to three different groups: first, who travelled from anywhere, and they migrated to this place. One of the key informant claimed that Athapahariya including Rai and Limbu had been belonging from Digarcha (mostly pronounced Dikcharya) of Tibet in eastern Nepal. The second group assimilated from larger hilly tribes namely Yakkha, Limbu and other Rais and other non-kirati groups like Thakuri and Katuwal. And, third group emigrated from the southern plain especially descendent of the King of Bijayapur. The first group claimed that they were aboriginal (Khambongwa) and later two groups were immigrated from different caste and ethnicity (Thangbongba) and all together settled in the lands of Dhankuta. They are grouped into fifteen sub-clan groups or Thars (Pachha) namely Khambongba of Hombrak, Chhara, Mangbung, Pangsung, Phokim, Khawaduk and Thangbongba of Chhitlinge, Kimdang, Chhongden, Charingme, Lengsuwa, Challe, Yakha, Patre and Roduwa. Moreover, Rai (2007) adds Parghari, Tumchha, Chamling, Pongyangu, Ingwa and Wasangri, although they are considered as a descendent of Limbu, Rais and Yakha.

\section{Gotra and Sammetling}

The Athapahariyas can also be divided into Kashi and Lhasa Gotra. Northey and Morris (1974) claim that Kashigotra emigrated from the south while Lhasa Gotra from the north. Same Thar is comprised into different Sub-thar or Sub-Pachha. For example, Chhitlinge is divided into Tikathar (Asima and Sahema), Bolithar (Asima and Sahema), Chikiwa and Torangwalang sub-Pachha. Asima emigrated from Lhasa while Sahema from the south. Sammetling is another important aspect of the Athapahariyas. Each and every Thar has its own Sammetling. Tunghaling Wapmayong for Chhitlinge, Wayami Wapmayong for Kimdang and Howere Wapmayong for Phokim are some examples of Sammetling. Kimdang one of the sub-thar of the different Athapahariyas thar was migrated there from Dhimal community (Diwas, 1982). Rai (2007) claimed that Kimdang was descendent of Tengmali Dhimal who lived in Morang and Jhapa districts. Indeed, Hodgson (1847) claims that all the Kirat people of Himalayan countries belong to the same stock of Tibeto-Burman groups. All these stocks may define as the location of experience, the containers of shapes, powers, feeling and meanings. Relph (1996) suggests the sense of place depends very much on familiarity of insidedness and outsidedness.

\section{Purification}

Athapahariya culture, trying to think only pure thought, is considered important for men and women to keep pure until he/she lived in the Athapahariya society. One of the main causes of purification in Athapahariya religion is to teach moral values, the act of removing from a person usually by a ceremony, the bad effects that they are suffering because they have abused of religious law. It is a symbol of purity and connected to unconscious knowing and being known somewhere (insidedness) 
while outsidedness is a relatively detached relation to place. Tututumyang is authorized purifier person who removes harmful substances from a man/woman who join in the Athapahariya Rais in a particular time and place. Meanwhile, the members of Mujulumba (an Athapahariya village council) namely Pujari or Yaba are legitimated to decide the times and materials for purification. They used traditional herbs, stone (Dubo-Dhungo) and Mantra (Tututumyang-Tumbali) to assist in purification in the place of Mangthanama (Jeemee/ Marga divinity). The members of Athapahariya, who join in this group to give his time, effort and love themselves, they believed that more resources are to be devoted to nature to earn their livelihood. This study found that both Khambongba and Thangbongba who belong to Athapahariyas are members to take part in a particular activity, either in Marga/Jeemee Puja or in the socio-cultural rituals.

\section{Land, Territory and Athapahariya Rais}

According to Cambridge Advanced Learner's Dictionary (200), land refers to the surface of the earth that is not covered by water. It is an area where living condition is good, we set foot on the surface and people have the opportunities to make a lot of foods. Land is an area of ground especially when used for a particular purpose such as farming, or building. Most of the family lived-off, the land, they worked the land all their lives and grew their own food. On the other hand, soil is the material on the surface of the ground is used variously like the activity of farming.

In the sense of the Athapahariya land and soils are used interchangeably and having good judgment, especially when it is based on practical ideas. Their understanding about the land or soil is living habitat and known as Khamukmaden. They realized that soil (Kham) is able in large degree to shape their physical appearance, mental structure and autonomy from neighbouring villages. Their sense is the ability to understand, recognize, value to something, especially any of the five physical abilities to see, hear, smell, taste and feel. With their keen sense of smell, they could tell if they were smoker from the other side of room. For example, their cold is so bad, they have lost their sense of smell or taste; they cannot smell or taste anything. Athapahariya sense is one of the possible meanings, they are not immigrants and it is good for the environment for their living. The feelings of Athapahariya have when there is an important event such as we born broken from the earth, we have no any father and mother, Kham is our mother and ultimately Khambongba known as our generic term. We belong to a lot of land or Jeemin and we are known as Jimdar or landlord.

\section{Relationships to Place}

Place is a portion of geographical space, sometime defined as territories of meaning (Cross, 2001). Sense of place instead, Athapahariya bring to the places where they live a whole set of cultural preoccupation that shape the way they respond to the place and in some measures reshape the place to fit those preoccupation (see in table 1). 
Table 1. Relationships between Athapahariyas and Different Places

\begin{tabular}{|c|c|c|}
\hline $\begin{array}{l}\text { The } \\
\text { Relationships }\end{array}$ & The Bounds & $\begin{array}{l}\text { The } \\
\text { Process }\end{array}$ \\
\hline Biological & $\begin{array}{l}\text { Historical } \\
\text { and } \\
\text { familial }\end{array}$ & $\begin{array}{l}\text { Athapahariya, a race is known as Kirant, who at the time of the Gorkha } \\
\text { conquest in } 1768 \text { were still an independent and whose territory was situated } \\
\text { to the bank of Tamor river. Under this name they occupied territory still more } \\
\text { extended up to the eastern boundary of Lumbukhola although they have own } \\
\text { their fixed boundary namely Guransedanda on the north, Tamor river on the } \\
\text { south, Tankhuwakhola on the east and Phongsuwakhola on the west. Dhankuta } \\
\text { is fact, their habitat and it is therefore they being born in this place, continue to } \\
\text { live and they have been dominated this place over the centuries. }\end{array}$ \\
\hline Spiritual & Emotional & $\begin{array}{l}\text { The spiritual meaning of place is an integral part of the Athapahariya Rais' } \\
\text { history. Such a tradition as this, without written documents, their origin of } \\
\text { diversity is to be found firstly in the various migrations which has brought } \\
\text { the present Athapahariya Rais, and secondly, in the difficulties of inter- } \\
\text { communication imposed by the geographical features. They have characterized } \\
\text { by a strong sense of identity with place and a relatively long residence. Their } \\
\text { attachment is based on feeling a sense of place belonging to simply felt rather } \\
\text { than created because they seem to be more of an intuitive connection than an } \\
\text { emotional, cognitive, or material connection sometimes mystical, and often } \\
\text { intangible. }\end{array}$ \\
\hline Ideological & $\begin{array}{l}\text { Moral } \\
\text { and } \\
\text { ethical }\end{array}$ & $\begin{array}{l}\text { Live according moral guide lines for their responsibility to place, guidelines } \\
\text { may be religious or secular. The strongest type of their attachment is } \\
\text { rootedness. Those Athapahariyas who have a strong sense of attachment, } \\
\text { identification, and involvement in their community. A sense of rootedness } \\
\text { means all members of the Athapahariyas lived in this territory their whole } \\
\text { life, strongly identifies with Marga and Jeemee and expects hopes to live there } \\
\text { until dies. On the other hand, unrootedness are alienated often have a negative } \\
\text { assessment of the place, do not identify with the place and are not highly } \\
\text { satisfied with the place. }\end{array}$ \\
\hline Narrative & Mythical & $\begin{array}{l}\text { Learning about place through stories, including creation, myths, family } \\
\text { histories, political accounts. Home (Pang) is mostly a place of security and } \\
\text { comfort, a place in which an Athapahariya develops a conception of self. } \\
\text { Home is occupied by their families in which other family members impossible } \\
\text { to develop an individual conception of self. Home is only one type of place } \\
\text { they relate to sleeping, cooking, storing and offering rites and passages. }\end{array}$ \\
\hline Commoditified & Cognitive & $\begin{array}{l}\text { Choosing a place based a list of desirable traits and lifestyle preferences namely } \\
\text { subsistence agriculture, animal husbandry, petty trading, cottage industry and } \\
\text { migration. Every member of Athapahariyas who fit into this environment has } \\
\text { lived in so many places in their life that they are not strongly rooted to any } \\
\text { particular community. }\end{array}$ \\
\hline Dependent & Material & $\begin{array}{l}\text { Constrained by lack of choice dependency on another person or economic } \\
\text { opportunities }\end{array}$ \\
\hline
\end{tabular}

(Developed by Author).

\section{Placelessness}

Dictionary meaning of 'place' is a position in relation to other things or people, if something is in place. It is its usual or correct position where everything in its place means that the best way to stay tidy and well organized is to keep things in their correct position (Cross, 2001). Athapahariya community gives importance on place for their comfortable lifestyle in Dhankuta for the periods of centuries. Their placement refers to the temporary position for their activities. In their place means 
every member of the Athapahariya Rais has given more importance to them and their thought. While in place means something is in place, it is its usual meaning and correct position where their home is placed. On the insider meaning if Athapahariya member is on the inside, he/she has involved in the operation of different activities in which (he/she) has special or secrete information who do he/ she know on the inside in the Athapahariya society. Inside means into a room, building, container or something similar to search a place very thoroughly, to have a special position within an organization or special relationship with a person that gives them advantages that other people do not have.

The final category of the Athapahariyas attachment is placelessness. Placelessness is characterized by a lack of place-based identification and a lack of emotional attachments to particular places. The main difference between relativity and placelessness is that in relativity people have a mobile sense of "home" and can cultivate a sense of home wherever they are in placelessness people do not have an articulated or place-based sense of home. They moved to Tarai does not identify any other place as home. Insider means who is an accepted member of the Athapahariya and who therefore has special or secrete knowledge or influence. According to insider the community is having got the information.

Outsider is a person who is not involved with a particular group of people or organization who does not live in a particular place. Outsiders have glamorized idea of what it is like to work for the community. A person who is not liked or accepted as a member of a particular group or organization or society and he feels different from these people who are accepted as a member.

\section{Conclusion}

The Athapahariya members have claimed that their place is sensitive to their needs and their sentiment is based on a feeling about a situation in the operation of activities. The successful integration, within place of their needs and economic and social potentialities must, therefore, be based on full knowledge of the geographical background. Sense of place, instead, they bring to the places where they live a whole set of cultural preconceptions that shape the way they respond to the place, and in some measure reshape the place to fit those preconceptions. It was easy for them to understand sense of place for a person who had a strong bond with one place. They had a much harder time trying to characterize a sense of place for the Athapahariya who described strong bonds with one place and very weak ones with another. The first aspect, relationship to place, consists of the ways that Athapahariya relates to places, or the types of bonds they have with places. The second aspect, their attachment, consists of the depth and types of attachments to one particular place. The submergence of places are like and its distinctiveness. The globalization of the economy and the all forms of human activity remove variations and distinctive features. A place can no longer be explained as the result of vertical humanity and land relations; horizontal relations will link any place to larger part of the world.

\section{References}

Bista, D. B. (1960). People of Nepal. Kathmandu: Ratna Book Distributors.

Central Bureau of Statistics (CBS). (2012). National Population and Housing Census 2011. Kathmandu. Author.

Claval, P. (2002). An Introduction to Regional Geography. New Delhi: Blackwell Publishers Limited. Cross, J. E. (2001). What is Sense of Place? Colorado: Colorado State University. 
Dahal, D. R. (1985). An Ethnographic Studies of Social Change Among the Athapahariya Rais of Dhankuta. A Report Submitted to Center for Nepal and Asian Studies, Tribhuvan University, Kirtipur.

Diwas, T. (1982). Dhimal Lokdharma Ra Sanskriti. Kathmandu: Royal Nepal Academy.

Hodgson, B. H. (1847). Essay the First on the Koch, Bodo and Dhimal Tribes. Calcutta: Vasistha Mission Press.

Kandangwa, K. M. (1993). Athapahariya Rai Jatiko Dincharya. Kathmandu: Royal Nepal Academy.

Khatiwada, S. P. (2006). Athapahariya Rai Jatiko Bhoutik Lok Sanskritik Sampada Ek Adhyan. Kathmandu: Nepali Folklore Society, Field Report.

Ministry of Information and Communication (MOIC) (1974). Mechidhekhi Mahakali, Part 1.Kathmandu: Author.

Northey, B. \& Morris, K. (1928). The Gurkhas. New Delhi: Cosmo Publishers.

Prapannacharya, S. (1994). Kiratko Prachin Itihas. Banarasi (India): Kirateswar Publisher.

Sorre, M. (1962). The concept of genre de vie. In L. Wagner \& M. W. Mikesell (Eds.), Readings in Cultural Geography (pp. 399-466). Chicago: The University of Chicago, Press:

Tuan, Y. F. (1995). Home and world, cosmopolitanism and ethnicity: key concept in contemporary human geography. In I. Douglas, R. Huggett \& M. Robinson (Eds.), Companion Encyclopedia of Geography (pp. 939-951).London: Routledge Publication.

Tuan, Y. F. (1974). Topophilia: A Study of Environmental Perception, Attitudes, and Values. New York: Columbia University Press.

Yin, R. K. (2003).Case study research: Design and method (3rd ed.). Thousand Oaks, CA: Sage. 